\title{
CYCLOSORUS FUKIENENSIS CHING (THELYPTERIDACEAE): A NEW RECORD FOR THE FLORA OF VIETNAM
}

\author{
Doan Hoang Son ${ }^{1}$, Tran The Bach ${ }^{1}$, Bui Hong Quang ${ }^{1}$, \\ Lu Thi Ngan', Sy Danh Thuong ${ }^{3 *}$ \\ ${ }^{1}$ Institute of Ecology and Biological Resources - Academy of Sciences and Technology, \\ ${ }^{2}$ Vietnam National Museum of Nature - Vietnam Academy of Science and Technology, \\ ${ }^{3} T N U$ - University of Education
}

\section{ABSTRACT}

Cyclosorus fukienensis Ching (Thelypteridaceae), a new record for the flora of Vietnam, was studied, compared and described. Before, this species only distributed in China (Fujian, North Guangdong, South Hunan, South Jiangxi, South Zhejiang). This species differs from the closely related species Cyclosorus interruptus (Willd.) H. Itô and Cyclosorus acuminatus (Houtt.) Nakai in its shape of the stipe bases, lobed, veinlets, soris, spores. In this paper, we introduce original reference and relevant references, type, detail morphological descriptions, distribution and habitat, specimens examined, color photograph, the key and the table compares the characteristics with the close species (Cyclosorus interruptus (Willd.) H. Itô, Cyclosorus acuminatus (Houtt.) Nakai). Specimens of Cyclosorus fukienensis Ching were collected in Kbang district, Gia Lai province and kept in the Herbarium of the Institute of Ecology and Biological Resources, Hanoi, Vietnam (HN). This research provides the checklist of vascular plants for the flora of Viet Nam.

Keywords: Cyclosorus, Cyclosorus fukienensis, Thelypteridaceae, new record, Vietnam

Received: 06/01/2020; Revised: 11/4/2020; Published: 29/4/2020

\section{CYCLOSORUS FUKIENENSIS CHING (THELYPTERIDACEAE): MỘT LOÀI BỔ SUNG CHO HỆ THỰC VẬT VIỆT NAM}

\author{
Doãn Hoàng Sơn', Trần Thế Bách¹, Bùi Hồng Quang1, \\ Lữ Thị Ngân², Sỹ Danh Thường ${ }^{3 *}$ \\ ${ }^{1}$ Viện Sinh thái và Tài nguyên sinh vật - Viện Hàn lâm Khoa học và Công nghệ Việt Nam, \\ ${ }^{2}$ Bảo tàng Thiên nhiên Việt Nam - Viện Hàn lâm Khoa học và Công nghệ Việt Nam \\ ${ }^{3}$ Truò̀ng Đại họ Su pham - ĐH Thái Nguyên
}

\section{TÓM TẮT}

Cyclosorus fukienensis Ching (Thelypteridaceae), loài bổ sung cho hệ thực vật Việt Nam đã được nghiên cứu, so sánh và mô tả. Trước đây, loài này chỉ được ghi nhận có ở Trung Quốc (Phúc Kiến, phía Bắc tỉnh Quảng Đông; phía Nam tỉnh Hồ Nam, Giang Tây và Chiết Giang). Loài này khác với loài Cyclosorus interruptus (Willd.) $\mathrm{H}$. Itô và Cyclosorus acuminatus (Houtt.) Nakai bởi các đặc điểm về gốc cuống, thùy, gân bên, túi bào tử, bào tử. Trong bài báo này, chúng tôi giới thiệu tài liệu gốc và các tài liệu khác liên quan đến loài, mẫu type chuẩn, mô tả chi tiết các đặc điểm hình thái, phân bố và sinh thái, mẫu nghiên cứu, ảnh màu minh họa, khóa định loại và bảng so sánh các đặc điểm với các loài gần gũi. Mẫu tiêu bản của loài Cyclosorus fukienensis Ching được thu tại huyện Kbang, tỉnh Gia Lai và được lưu giữ tại phòng tiêu bản thực vật $(\mathrm{HN})$ của Viện Sinh thái và Tài nguyên sinh vật. Kết quả nghiên cứu góp phần bổ sung danh lục thành phần loài thực vật bậc cao có mạch cho hệ thực vật Việt Nam.

Từ khóa: Cyclosorus; Cyclosorus fukienensis; Thelypteridaceae; loài bổ sung; Việt Nam.

Ngày nhận bài: 06/01/2020; Ngày hoàn thiện: 11/4/2020; Ngày đăng: 29/4/2020

* Corresponding author. Email: thuongsd@dhsptn.edu.vn

DOI: https://doi.org/10.34238/tnu-jst.2020.05.2515 


\section{Introduction}

Cyclosorus is the genus of Thelypteridaceae, comprising about 250 species and commonly distributed in tropical and subtropical regions of the Old World, most in Asia, several species in the New World [1]. In Japan, five species of Cyclosorus were found by O-Shida Ka [2]. Twenty six taxa of Cyclosorus are confirmed in Indochina regions [3] and nine species are distributed in Vietnam [4]. Recently, while field work in Kon Chu Rang Nature Reserve, Kbang district, Gia Lai province $\left(14^{0} 28^{\prime} 19^{\prime \prime} \mathrm{N}, 108^{0} 32^{\prime} 21^{\prime \prime} \mathrm{E}\right)$ at an elevation $(927 \mathrm{~m})$, we collected a species of Cyclosorus. The species differs from the closely related species Cyclosorus interruptus and Cyclosorus acuminatus in its shape of the stipe bases, lobed, veinlets, sori, spores (Table 1). Based on the basis of available literatures [1], [4] and carefully studying a type specimen, finally it was identified as Cyclosorus fukienensis Ching for the first time from Vietnam. Previously its distribution has been known only in Fujian, N. Guangdong, S. Hunan, S. Jiangxi, S. Zhejiang of China. In this study, we reported Cyclosorus fukienensis as a newly added taxon to the Flora of Vietnam and its description, habitat, color photographs and key of related taxa are provided.

\section{Material and methods}

Material: The morphological studies were based on the field observations and the sample collected from the Kon Chu Rang Nature Reserve and documents of surround nations. Specimens housed in Institute of Ecology and Biological Resources, Ha Noi, Vietnam (HN).

Method: We have applied the morphological comparison method in this study.

\section{Results and discussion}

\section{Taxonomic treatment:}

Cyclosorus fukienensis Ching, Bull. Fan Mem. Inst. Biol., Bot. 8(4): 209-210. 1938. - TYPE: China (Fujian Samsa); Matthew, C.G., \#s.n.
Plants 40-100 cm tall. Rhizomes long creeping, including stipe bases with dark brown lanceolate scales and setae. Fronds distant; stipes 10-30 cm; laminae 30-80 × 15$30 \mathrm{~cm}$; bases gradually narrowed or slightly so; apices caudate with a medium-sized to large apical pinna; pinnae 5-15 pairs, shortly stalked or almost sessile, proximal 1-5 pairs gradually shortened, or sometimes only 1 pair slightly shortened; middle pinnae lanceolate, $10-18 \times 1.5-3 \mathrm{~cm}$, bases truncate or broadly cuneate, lobed 1/5-1/3 toward costae, apices acuminate; segments 20-30 pairs on middle pinnae, $2-4 \times 3-5 \mathrm{~mm}$, obtuse or sub-truncate at apices; veinlets 5-10 pairs, proximal 2 pairs anastomosing, next $1.5-2$ pairs running to sinus membrane. Laminae papery, grayish green or brownish green when dried, with short acicular hairs along costae and veins and minute hairs between veins on both surfaces, also clavate glands on stalks. Sori orbicular, usually at middle of veinlets; indusia orbicular-reniform, membranous, persistent. Sporangia bearing glands. Spores with short fimbriate wings (Figure 1).

Distribution and habitats: Vietnam (Gia Lai); Fujian, N. Guangdong, S. Hunan, S. Jiangxi, S. Zhejian. The species growing at wet places in forests and forest margins.

Specimens examined: VIETNAM. Gia Lai province: Kbang district, 2018, Doan Hoang Son et al. Son 58 (HN).

\section{A key to Cyclosorus fukienensis and some species related taxa in Vietnam}

1. Proximal 2 pairs anastomosing, next $1.5-2$ pairs running to sinus membrane

Cyclosorus fukienensis

1'. Proximal pair anastomosing, next 0.5-1.5 pair running to sinus membrane

2. Spores with sparsely minutely echinulate ..Cyclosorus interruptus

2'. Spores with densely cristate. Cyclosorus acuminatus 


\section{Conclusion}

1. Building the key to distinguish Cyclosorus fukienensis from other species of Cyclosorus in Vietnam. It is a new record to the flora of Vietnam.

2. The morphological characteristics and others information of Cyclosorus fukienensis have been described including loc.class., type, distribution, research specimen and color photographs.

Acknowledgments: We thank the IDEA WILD Foundation for supporting equipment to conduct this research.

\section{REFERENCES}

[1]. J. X. J. Ke, L. Youxing, L. Zhongyang, K. Iwatsuki and A. R. Smith, Flora of China, Science Press \& Missouri Botanical Garden Press, Beijing \& St. Louis, vol. 2-3, pp. 372386, 2013.

[2]. J. Ohwi, Flora of Japan. Smithsonian Institution, Washington D.C., 1965, pp. 76-77.

[3]. F. Gagnepain, In Flore générale de l'IndoChine, Lecomte, H. (ed.), Muséum National d'Histoire Naturelle, Laboratoire de Phanérogamie, Paris, (in French), vol. 7, pp. 378-400, 1941.

[4]. H. H. Pham, An Illustrated Flora of Vietnam. Tre Publishing House, Hanoi, Vietnam, vol. 1, 2003, pp.127-142.

Table 1. Morphological comparison of C. fukienensis, C. interruptus and C. acuminatus

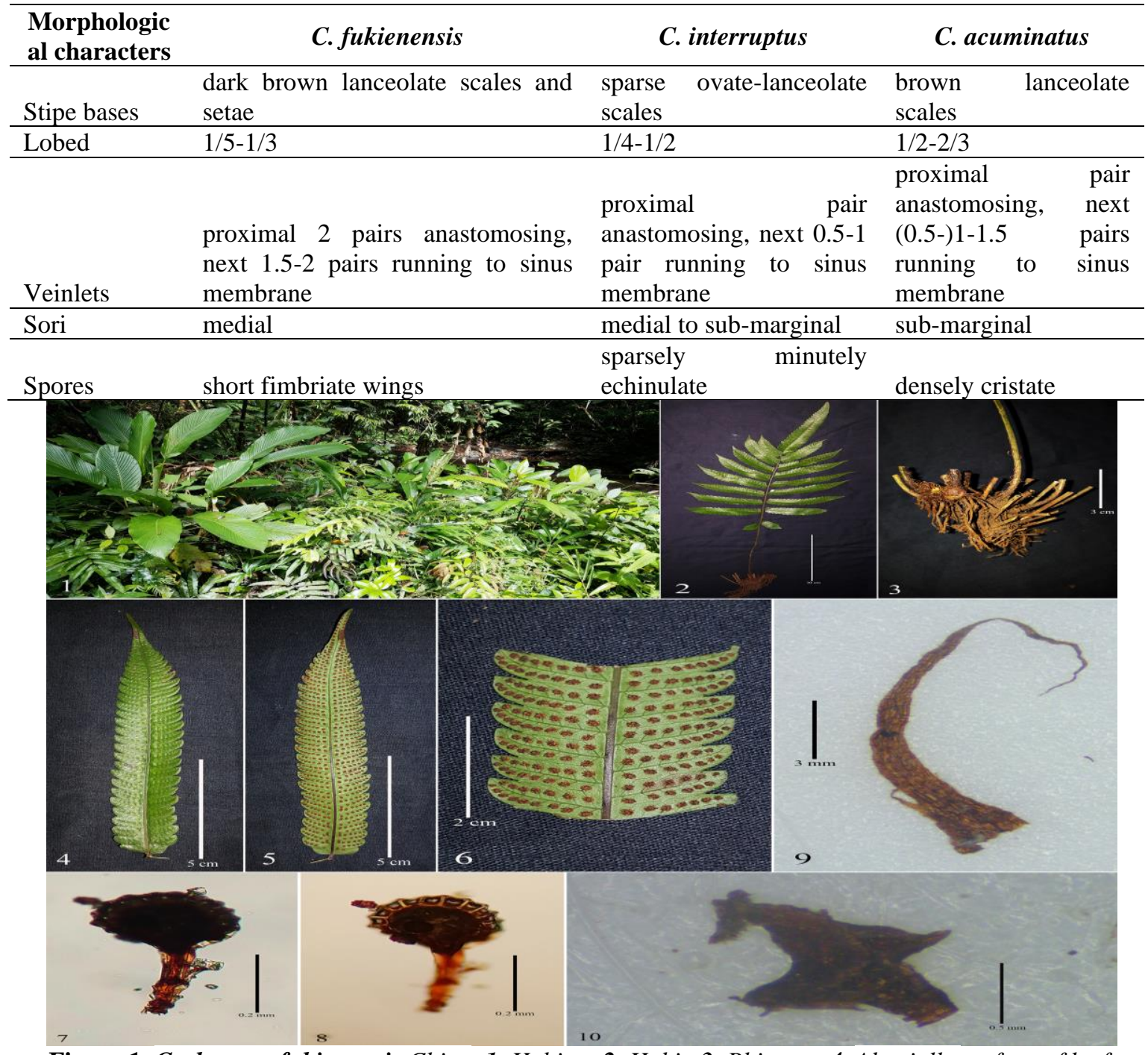

Figure 1. Cyclosorus fukienensis Ching. 1. Habitat. 2. Habit. 3. Rhizome. 4. Abaxially surface of leaf. 5. Adaxially surface of leaf. 6. Sori and veinlets. 7-8. Sporangia. 9. Scale. 10. Indusia. 